\title{
Assessment of eco-diversity status of Homalomena aromatica (Spreng.) Schott and its habitat in tropical forest of Indian Eastern Himalaya
}

\author{
K Ronald, P R Gajurel*, B Singh \\ Forest Systematic and Ethnobiology Laboratory, Department of Forestry, North Eastern Regional Institute of Science and Technology, \\ Nirjuli 791109, Arunachal Pradesh, India
}

\section{Article history}

Received: 26 October 2018 Accepted: 10 January 2019

Published: 01 April 2019

\section{Editor}

Prof. Manuel Losada Gavilanes Federal University of Lavras Lavras, Brasil

\section{Publisher}

Horizon e-Publishing Group

\author{
*Correspondence \\ Padma Raj Gajurel \\ $\triangle$ prgajurel@gmail.com
}

\begin{abstract}
Homalomena aromatica (Spreng.) Schott is one of the economically important plant species occurring in the North east and Eastern Himalayan region of India which received least attention in its ecological and conservation studies. The current study has been undertaken in the north eastern state of Arunachal Pradesh. The population, phytosociological status of its habitat, regeneration and species association of $H$. aromatica were worked out using standard ecological methods. Out of the 15 selected forest sites for survey, $H$. aromatica was found only in 9 sites. A total of 288 species representing 99 families are documented from the selected sites where Euphorbiaceae, Meliaceae, Araceae, Dipterocarpaceae and Poaceae are found dominant in all the 9 sites. Species diversity index $\left(\mathrm{H}^{\prime}\right)$ of all the three habits i.e. the tree, shrub, and herb were found highest in Happy Valley site followed by Ganga Lake. A total of 219 individuals of $H$. aromatica recorded which were found confined within the altitudinal ranges of $350 \mathrm{~m}-450 \mathrm{~m}$ asl. The IVI (1.95 to 9.64) and Frequency \% (5 to 12.5) range of $H$. aromatica found significantly low at all the survey sites. Pearson's correlation analysis reveals that there is a positive relationship between the population size and the species diversity index, where shrub showed the strongest relationship $(\mathrm{r}(7)=0.900, P=0.001)$ followed by tree $\mathrm{r}(7)=0.736, P=0.024$ and the herbs with weakest relationship $(\mathrm{r}(7)=0.39, P=0.269)$. The Chi-square test of association indicated significant association of 10 species with $H$. aromatica in the various sites where Alocasia acuminate (Aracaceae), Amomum sp. (Zingiberaceae) and Pteris sp. (Pteridaceae) showed highest association with higher Chi square value. The poor population status with average density of 3041.67/hectare and 8.89 frequency percentage as well the existing anthropogenic threats to the species recorded in the present study has warrants for its immediate conservation.
\end{abstract}

Keywords: Arunachal Pradesh; Tropical forest; Homalomena aromatica; Eastern Himalaya; Population status; Species association and Threats

Citation: Ronald K, Gajurel PR, Singh B. Assessment of eco-diversity status of Homalomena aromatica (Spreng.) Schott and its habitat in tropical forest of Indian Eastern Himalaya. Plant Science Today 2019;6(2):71-83. https://doi.org/10.14719/pst.2019.6.2.435

Copyright: (c) Ronald et al. (2019). This is an open-access article distributed under the terms of the Creative Commons Attribution License, which permits unrestricted use, distribution, and reproduction in any medium, provided the original author and source are credited (https://creativecommons.org/licenses/by/4.0/).

Indexing: Plant Science Today is covered by Scopus, CAS, AGRIS, CABI, Google Scholar, etc. Full list at http://www.plantsciencetoday.online

\section{Introduction}

One of the greatest challenges facing humanity is to halt the decline of biodiversity worldwide (1).
Moreover, rare species are at greater risk of extinction because of their small geographic ranges, low abundances, and greater susceptibility to environmental changes (2-5) and these rare species 
are important for the recognition of a local plant community (6). The genus Homalomena of Araceae family is although reported with more than 200 species, about 106 species are presently with accepted names (7). Out of 6 species recorded in India, 2 species namely Homalomena aromatica (Spreng) Schott and Homalomena pendula (Bl.) Hakh. are found in North east India and the rest 4 species are restricted to Andaman and Nicobar Island only (8). The studies on population and regeneration behavior of a species are needful in understanding the species life cycle and they also provide significant ecological data useful in formulation of conservation strategies (9). During the past few years study on ecology, distribution and population status of some rare and endangered plant species have been attempted by various workers. The study on Homalomena bellula Schott by Kusuma and Astuti (10); on Gymnocladus assamicus by Choudhury et al. (11); on Paris polyphylla by Paul et al. (12); on Pinus merkusii by Das et al. (13) are found significant which generates various useful information for conservation of rare and threatened species. The North east India with its eastern Himalaya is a home of numerous economically and ecologically important plant species and many of these species are becoming endangered with very limited population in the natural habitats. The Homalomena aromatica (Photo plate 1) is one of such species which qualify for its population assessment for its future management.

Background of the Species: Homalomena aromatica (Spreng.) Schott also known as "Sughandmantri" is a rhizomatous aromatic perennial herb, belonging to Araceae family of Monocotyledon. Its essential oils of the species reported to have various medicinal and industrial uses along with antimicrobial activities. Besides the uses in perfumery and cosmetic industries, it is used traditionally for cold and cough, jaundice, stomach problems, skin diseases, etc. and also possesses antioxidant properties (14). The plant has two trademarks, Sugandhimantri (dry rhizome) and Montria oil which are used in perfume, cosmetic and dhup (incense) industries (15). It is also reported that ethnobotanically the species is used in various forms like vegetable, medicine, etc. in different states of North eastern region of India and in Maulvibazar district of Bangladesh (16-21). It is observed that the plant is having potential antibacterial activity (22-24). The ulcer protective activity from the ethanolic extracts of $H$. aromatica was also reported (25). The essential oil from the species is reported of having insect repellent activity (26). The Indian Red Data Book (28) listed 620 rare and endangered plant species in India but $H$. aromatica was not included in the list. However, Ved et al. (29) listed 51 threatened species from north east regions of India, where $H$. aromatica is categorized under Endangered in Assam and Vulnerable in Arunachal Pradesh. At present there is only one species i.e. Homalomena lauterbachii Engl. listed in IUCN Red List as Least Concern (27). The $H$. aromatica is mostly encountered in the foothills of Indian Eastern Himalayan states. The recent phytosociological studies on medicinal plants from the state has mostly conducted in high altitudinal forests $(12,30,31)$ which do not provide any information of the species. As the species is assume to be a rare and endangered in the north eastern region and also been exploited for both commercially and locally, there is a need of understanding its real status of occurrence in its natural habitat so that specific conservation strategy can be formulated. In this context the present study has been undertaken for better understanding the population and regeneration status, species association, relation between species diversity and population size with various threats of $H$. aromatica in Arunachal Himalaya.

\section{Material and Methods}

\section{Exploration Area:}

The Indian Eastern Himalayan regions consist of five political territories of which three are under Indian territory; Darjeeling (West Bengal), Sikkim and Arunachal Himalaya. The others are Nepal and Bhutan Himalaya (32). The present study was undertaken in the Arunachal Himalaya which is located in the extreme north eastern part of India $\left(27.06^{\circ} \mathrm{N}\right.$ and $\left.93.37^{\circ} \mathrm{E}\right)$. Based on the distributional records and habitat preferences of the Homalomena aromatica (Spreng.) Schott, 15 specifics most diverse forest sites from six districts of Arunachal Pradesh were selected for preliminary field exploration and identification of sites for population study. The details of the study sites with their GPS points along with the inhabiting tribes in the locality are presented in Table 1 . The study sites were predominantly hilly and mountainous in nature. The forest of the study sites falls under Tropical semi evergreen (2/B/C1/Ia, 2/B/C1b/ISI), Tropical evergreen (1/B/C1, $1 / \mathrm{B} / \mathrm{C} 2)$, (33), and mixed bamboo forest as per Kaul \& Haridasan (34).

\section{Sampling Method:}

The field surveys were conducted based on the secondary information and consultation with the local communities. Preliminary surveys in 15 sites covering the 6 districts of Arunachal Pradesh were undertaken during November, 2015 to December, 2016. Based on the accessibility and availability of the species, 9 distinct sites of $1 \mathrm{~km} \mathrm{x} 1 \mathrm{~km}$ size were selected from 3 districts (Fig. 1). Vegetation sampling of all the three habits (tree, shrub, and herb) was done through random quadrates methods. Twenty quadrates of $10 \mathrm{~m} \times 10 \mathrm{~m}$ were laid in each selected plot for tree species and individuals with diameter at breast height (DBH) more than $15 \mathrm{~cm}$ where recorded. Within the $10 \mathrm{~m}$ $\mathrm{x} 10 \mathrm{~m}$ quadrate two numbers of $5 \mathrm{~m} \times 5 \mathrm{~m}$ quadrate 

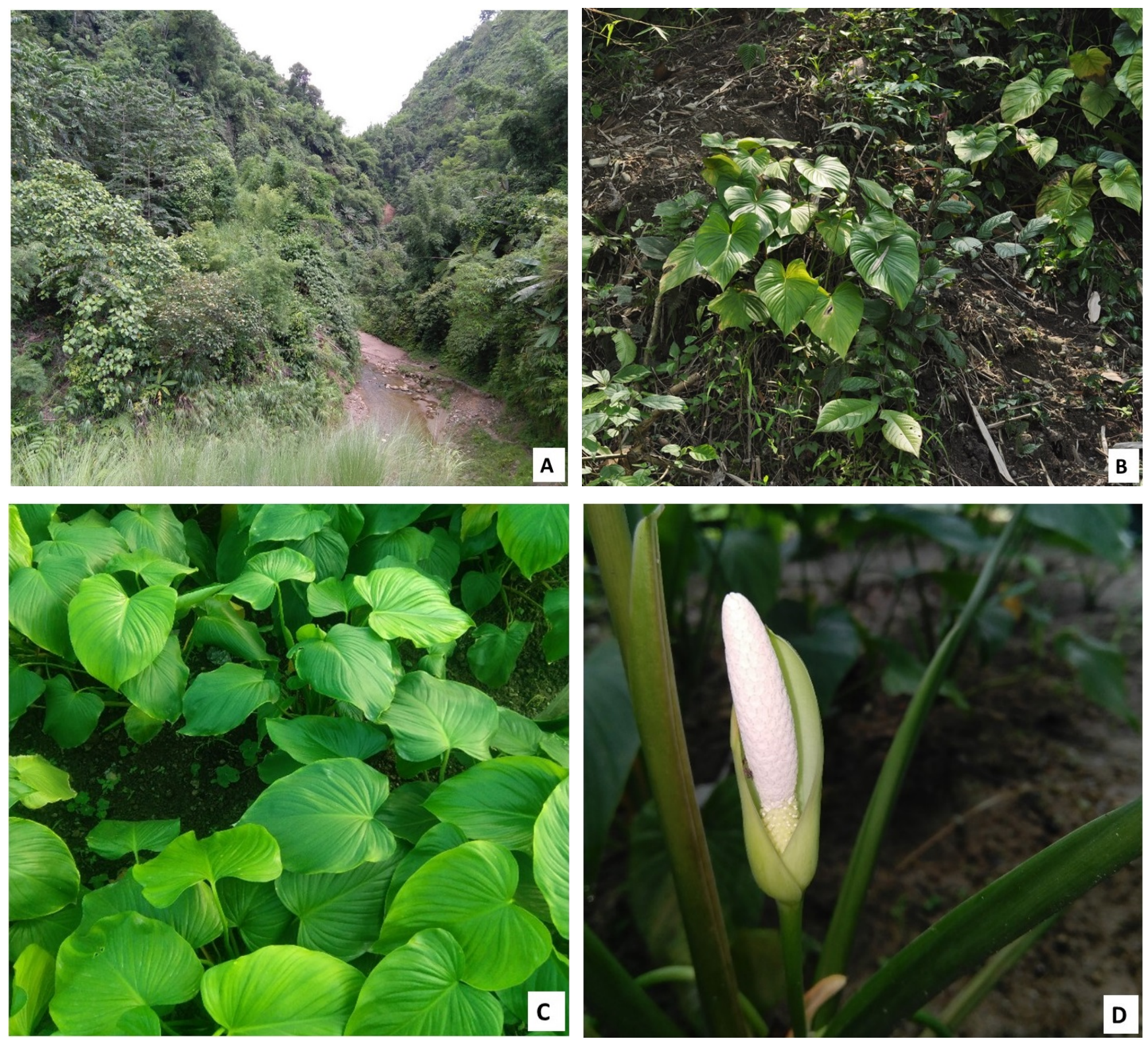

Photo Plate 1: Homalomena aromatica (spereng.) Schott and its habitats A. Habitat of the species, B. Species in its natural habitat, $\mathrm{C}$. The species grown in nursery and D. Inflorescence.

for shrub and four $1 \mathrm{~m} \times 1 \mathrm{~m}$ quadrate for herb species were plotted. Specimens of all species were collected and herbarium specimens were prepared (35) and identification was done following taxonomic literature and herbarium specimens of regional and national herbaria (ASSAM and ARUN). The community characteristic of the selected sites was studied using quantitative analytical methods. Important ecological parameters like density, frequency, abundance, importance value index (IVI) were calculated using standard methods $(36,37)$. Species diversity index $\left(\mathrm{H}^{\prime}\right)$ was also calculated following Shannon \& Weaver (38). An attempt has also been made to know whether there is any mutual relationship between the species diversity of the habitat and the population of Homalomena aromatica in the study sites. So, Pearson's correlation test (r) was used to analyses the relationship using software IBM SPSS statistics 19 (39). Data on population structure for the species $H$. aromatica occurring at the sites was collected at two levels, namely young (Y) and adult (A). The individuals, with $\leq 15 \mathrm{~cm}$ height were considered as young plant while individuals with $\geq 30 \mathrm{~cm}$ height were considered as adult plant. The relative proportion of young and adults of the species at each study site was calculated. The distribution pattern of $H$. aromatica was also calculated as per the following formula (40).

$$
\text { Distribution pattern }=\frac{\text { Abundance }}{\text { Frequency }}
$$

The distribution pattern was determined if the $\mathrm{A} / \mathrm{F}$ ratio is $<0.025$ (as regular $n$ ); between 0.025 and 0.05 (random) and $>0.05$ (contagious or clumped).

Regeneration status was determined based on the data of population size of young and adult plant (41). As the targeted species is a rhizomatous herb, so the regeneration status was considered only in two stages i.e. young and adult. The categorization is set as (a) good regeneration, if 


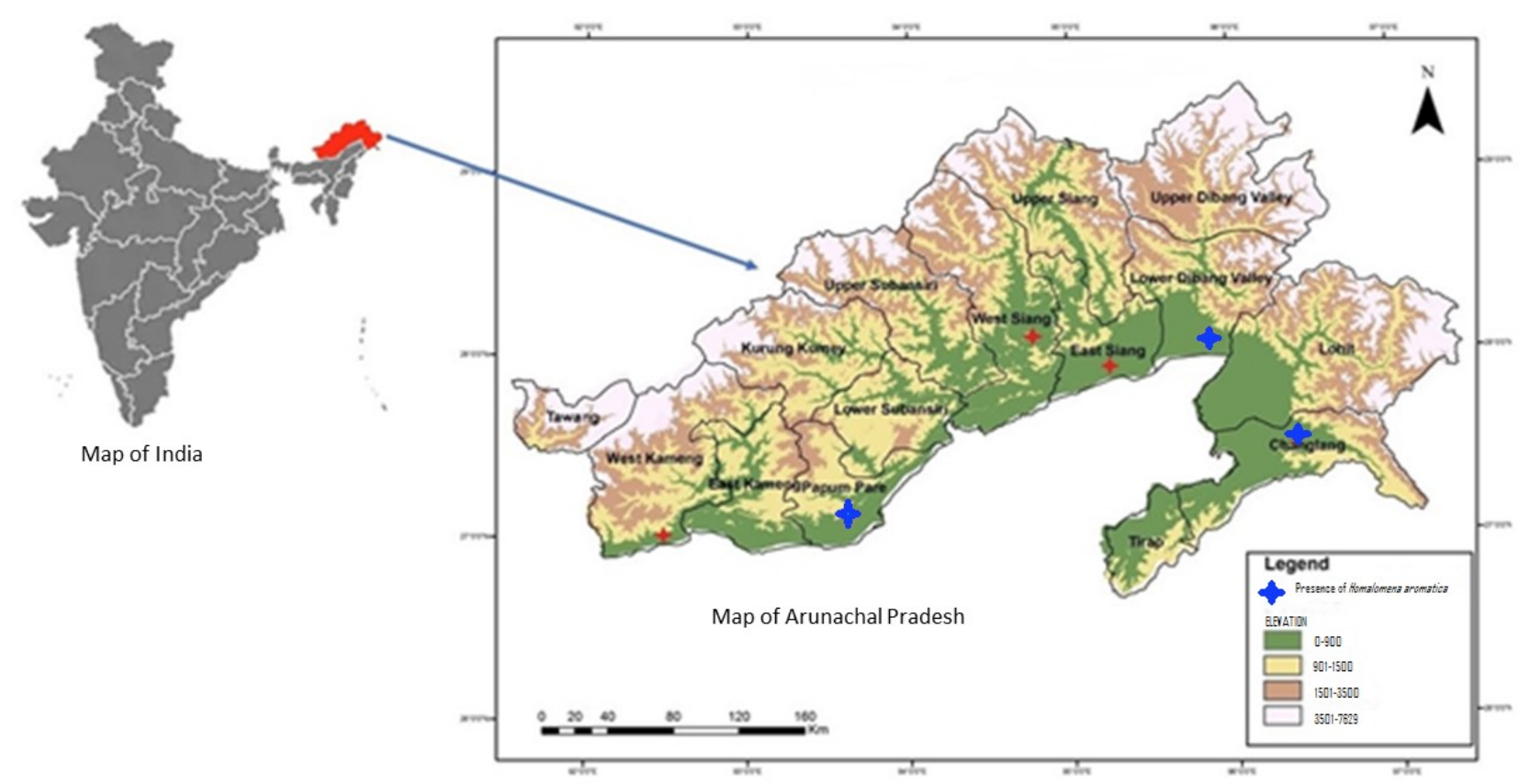

Fig. 1. Map of Arunachal Pradesh indicating the study sites

Table 1: Details of the study sites

\begin{tabular}{|c|c|c|c|c|c|}
\hline Sl No. & District & Major Tribe & Survey Sites & Geographic location & Elevation \\
\hline \multirow{3}{*}{1} & \multirow{3}{*}{ Papumpare } & \multirow{3}{*}{ Nishi } & Banderdewa & $27^{\circ} 06^{\prime} 19.8^{\prime \prime N} 93^{\circ} 49^{\prime} 19.29^{\prime \prime E}$ & \multirow{3}{*}{$120-400 \mathrm{~m}$ asl } \\
\hline & & & Karsingsa & $27^{\circ} 06^{\prime} 24.52 " \mathrm{~N} 93^{\circ} 46^{\prime} 31.55^{\prime \prime} \mathrm{E}$ & \\
\hline & & & Ganga Lake & 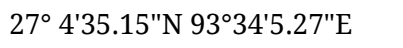 & \\
\hline \multirow{2}{*}{2} & \multirow{2}{*}{ West Kameng } & \multirow{2}{*}{$\begin{array}{l}\text { Monpa, Aka, } \\
\text { Shertokpen }\end{array}$} & Bhalukpong & 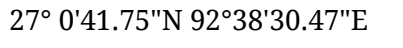 & \multirow{2}{*}{$150-213 \mathrm{~m}$ asl } \\
\hline & & & Tipti & $27^{\circ} 2^{\prime} 7.37^{\prime \prime N} 92^{\circ} 36^{\prime} 19.78^{\prime \prime E}$ & \\
\hline \multirow{2}{*}{3} & \multirow{2}{*}{ East Siang } & \multirow{2}{*}{ Adi } & Pasighat (Belak) & $28^{\circ} 3^{\prime} 49.98^{\prime \prime N} 95^{\circ} 17^{\prime} 10.13^{\prime \prime E}$ & \multirow{2}{*}{$153-380 \mathrm{~m}$ asl } \\
\hline & & & Pasighat (Mirbuk) & 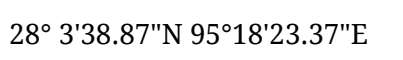 & \\
\hline \multirow{2}{*}{4} & \multirow{2}{*}{ West Siang } & \multirow{2}{*}{ Galo } & Aalo & 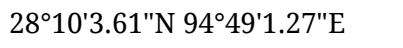 & \multirow{2}{*}{$600-750 \mathrm{~m}$ asl } \\
\hline & & & Jirdin & $28^{\circ} 9^{\prime} 12.89 " \mathrm{~N} 94^{\circ} 50 ' 38.46^{\prime E}$ & \\
\hline \multirow{3}{*}{5} & \multirow{3}{*}{$\begin{array}{l}\text { Changlang } \\
\text { (Namdapha } \\
\text { National Park) }\end{array}$} & \multirow{3}{*}{$\begin{array}{l}\text { Lisu, Tangsa, } \\
\text { Shingpho }\end{array}$} & Happy Valley & $27^{\circ} 31^{\prime} 09.63^{\prime \prime} \mathrm{N} 96^{\circ} 23^{\prime} 53.51^{\prime \prime} \mathrm{E}$ & \multirow{3}{*}{$400-600 \mathrm{~m}$ asl } \\
\hline & & & Near Hornbill Camp & $27^{\circ} 32^{\prime} 24.2^{\prime \prime} \mathrm{N} 96^{\circ} 24^{\prime} 33.0^{\prime \prime} \mathrm{E}$ & \\
\hline & & & Deban Camp & $27^{\circ} 32^{\prime} 21.24^{\prime \prime} \mathrm{N} 96^{\circ} 23^{\prime} 42.28^{\prime \prime} \mathrm{E}$ & \\
\hline \multirow{3}{*}{6} & \multirow{3}{*}{$\begin{array}{l}\text { Lower Dibang } \\
\text { Valley }\end{array}$} & \multirow{3}{*}{ Adi, Mishing } & Koronu & $28^{\circ} 4^{\prime} 36.22 " \mathrm{~N} 95^{\circ} 55^{\prime} 19.54 " \mathrm{E}$ & \multirow{3}{*}{$350-500 \mathrm{~m}$ asl } \\
\hline & & & Bhismaknagar & 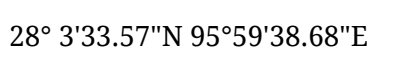 & \\
\hline & & & Abongo Camp & $28^{\circ} 5^{\prime} 52.00^{\prime \prime N} 95^{\circ} 54^{\prime} 24.92^{\prime \prime E}$ & \\
\hline
\end{tabular}

number of young plants > adults, (b) fair regeneration, if number of young plants $>$ or $\leq$ adults, (c) poor regeneration, if the number of young plant < adults, (d) no regeneration if young plant of a species were absent but only adults were present, and (e) new, if adults were absent, but only young stages of the species were present. To understand the species association of
Homalomena aromatica with other plant species in the study sites, a Chi-square test of association was used to indicate the probability that whether the two species are distributed independently, or are associated with one another (42). To quantify the strength of association which ascertains the species that are closely associated with the study species, the Cramer's V of association was 


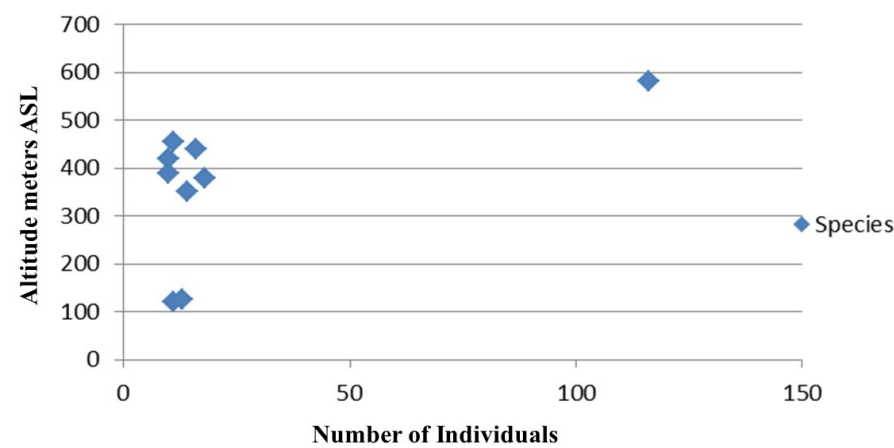

Fig. 2. Distribution of Homalomena aromatica based on altitudinal level

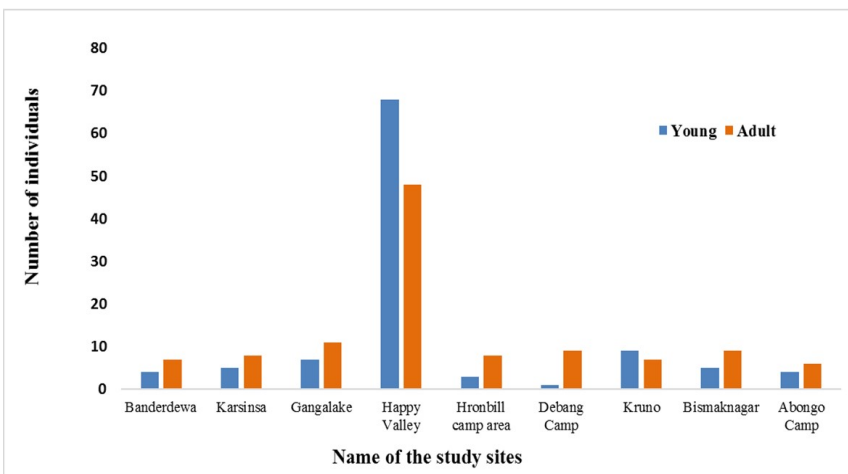

Fig. 3. Population structure of Homalomena aromatica in different study plots

Table 2: Community characteristic of the selected study sites

\begin{tabular}{|c|c|c|c|c|c|c|c|c|c|c|}
\hline \multirow{3}{*}{ Parameters } & \multirow{3}{*}{ Habit } & \multicolumn{9}{|c|}{ Study sites* } \\
\hline & & \multicolumn{3}{|c|}{ Papumpare district } & \multicolumn{3}{|c|}{ Lower Dibang Valley ditrict } & \multicolumn{3}{|c|}{ Changlang district } \\
\hline & & Site 1 & Site 2 & Site 3 & Site 1 & Site 2 & Site 3 & Site 1 & Site 2 & Site 3 \\
\hline \multirow{3}{*}{ Species richness } & Tree & 27 & 24 & 34 & 42 & 21 & 27 & 48 & 33 & 26 \\
\hline & Shrub & 20 & 19 & 21 & 18 & 21 & 20 & 32 & 22 & 20 \\
\hline & Herb & 36 & 25 & 22 & 33 & 38 & 25 & 34 & 41 & 24 \\
\hline \multirow{3}{*}{ No. Genus } & Tree & 21 & 21 & 30 & 40 & 18 & 24 & 40 & 30 & 26 \\
\hline & Shrub & 18 & 17 & 19 & 17 & 21 & 19 & 27 & 20 & 19 \\
\hline & Herb & 30 & 22 & 19 & 31 & 23 & 22 & 29 & 33 & 22 \\
\hline \multirow{3}{*}{ No. Family } & Tree & 19 & 17 & 22 & 29 & 18 & 17 & 29 & 21 & 18 \\
\hline & Shrub & 13 & 12 & 16 & 12 & 14 & 13 & 20 & 15 & 15 \\
\hline & Herb & 21 & 15 & 12 & 25 & 20 & 14 & 22 & 22 & 16 \\
\hline \multirow{3}{*}{$\begin{array}{c}\text { Species } \\
\text { Diversity } \\
\text { index }\left(H^{\prime}\right)\end{array}$} & Tree & 3.10 & 2.96 & 3.40 & 3.33 & 2.89 & 3.06 & 3.68 & 3.27 & 3.12 \\
\hline & Shrub & 2.75 & 2.71 & 2.90 & 2.77 & 2.89 & 2.83 & 3.31 & 2.95 & 2.84 \\
\hline & Herb & 3.31 & 3.07 & 2.91 & 3.19 & 3.02 & 3.08 & 3.41 & 3.55 & 3.00 \\
\hline \multirow{3}{*}{$\begin{array}{c}\text { Density } \\
\text { (Individual } \\
\mathrm{ha}^{-1} \text { ). }\end{array}$} & Tree & 820 & 475 & 895 & 955 & 595 & 550 & 1435 & 750 & 850 \\
\hline & Shrub & 3650 & 2510 & 2860 & 2070 & 3650 & 1890 & 6460 & 2320 & 2700 \\
\hline & Herb & 177750 & 153125 & 100750 & 168875 & 229375 & 145875 & 60093.75 & 103625 & 88000 \\
\hline \multirow{3}{*}{$\begin{array}{l}\text { Basal area } \\
\left(\mathrm{m}^{2} \mathrm{ha}^{-1}\right)\end{array}$} & Tree & 16.634 & 6.895 & 19.035 & 38.151 & 8.736 & 8.234 & 63.669 & 13.786 & 63.669 \\
\hline & Shrub & - & - & - & - & - & - & - & - & - \\
\hline & Herb & - & - & - & - & - & - & - & - & - \\
\hline
\end{tabular}

* Papumpare district: Site 1 = Banderdewa, Site 2 = Karsingsa, Site3 = GangaLake; Lower Dibang Valley district: Site 1 = Koronu, Site 2 = Bismaknagar, Site 3 = Abongo Camp; Changlang district: Site 1 = Happy Valley, Site 2 = Hornbill Camp area, Site 3 = Deban Camp

calculated (43). The strength was indicated as weak when the value is between 0.00 and 0.10 ; moderate if the value is between 0.11 and 0.30 and strong when the value is greater than 0.30 . To run the test of association, five herb species each from all the studied plots were selected based on the highest numbers of sharing in same quadrate with H. aromatica.

\section{Results}

The field exploration carried out in the selected 15 sites of the six districts (Table 1) resulted the occurrence of Homalomena aromatica only in 9 sites of the three districts (Table 3). So, the further study on the distribution, population structure, species composition and species association were carried out in those 9 sites where $H$. aromatica was present.

\section{Species composition and community characteristic in the habitats of $\boldsymbol{H}$. aromatica}

A total of 288 species representing 209 genera belonging to 99 families have been documented from the 9 forest sites. Among these, 116 are tree species representing 84 genera under 47 families; 72 species are shrubs belonging to 58 genera of 39 
Table 3: Occurrence of Homalomena aromatica in the studied plots

\begin{tabular}{|c|c|c|c|c|c|c|c|c|}
\hline $\begin{array}{l}\text { Sl. } \\
\text { No. }\end{array}$ & District & Survey Site & $\begin{array}{c}\text { No. of } \\
\text { Individuals* }\end{array}$ & $\begin{array}{c}\text { Frequency } \\
\%\end{array}$ & $\begin{array}{c}\text { Density } \\
\text { (Individual } \\
\mathrm{ha}^{-1} \text { ). }\end{array}$ & IVI & $\begin{array}{l}\text { Distribution } \\
\text { pattern }\end{array}$ & Threats \\
\hline \multirow{3}{*}{1} & \multirow{3}{*}{ Papumpare } & Banderdewa & 11 & 5 & 1375 & 1.95 & Clumped & \multirow{3}{*}{$\begin{array}{l}\text { Landslides, heavy flood, } \\
\text { road widening, } \\
\text { urbanization, and } \\
\text { collection of rhizome } \\
\text { and other resources }\end{array}$} \\
\hline & & Karsingsa & 13 & 7.5 & 1625 & 3.15 & Clumped & \\
\hline & & Ganga Lake & 18 & 12.5 & 2250 & 4.39 & Clumped & \\
\hline \multirow{3}{*}{2} & \multirow{3}{*}{$\begin{array}{c}\text { Changlang } \\
\text { (Namdapha } \\
\text { National Park) }\end{array}$} & Happy Valley & 116 & 21.25 & 14500 & 9.64 & Clumped & \multirow{3}{*}{$\begin{array}{l}\text { Plant is eaten as } \\
\text { vegetables by local } \\
\text { people }\end{array}$} \\
\hline & & Hornbill Camp area & 11 & 6.25 & 1375 & 3.06 & Clumped & \\
\hline & & Deban Camp & 10 & 5 & 1250 & 3.42 & Clumped & \\
\hline \multirow{3}{*}{3} & \multirow{3}{*}{$\begin{array}{c}\text { Lower Dibang } \\
\text { Valley }\end{array}$} & Koronu & 16 & 10 & 2000 & 3.61 & Clumped & \multirow{3}{*}{$\begin{array}{l}\text { Landslides, road } \\
\text { widening, deforestation } \\
\text { for agriculture and } \\
\text { collection of rhizome } \\
\text { and other resources. }\end{array}$} \\
\hline & & Bhismaknagar & 14 & 7.5 & 1750 & 2.66 & Clumped & \\
\hline & & Abongo Camp & 10 & 5 & 1250 & 2.25 & Clumped & \\
\hline
\end{tabular}

Total number of individuals recorded from all the sites is 219 .

families and, 99 species are herbs under 74 genera of 46 families.

Among all the sites, the species richness is found highest in the sites of Changlang district with 177 species under 148 genera and 88 families followed by sites of Lower Dibang Valley district with 140 species under 117 genera and 67 families and lowest in Papumpare district with 136 species from 113 genera and 62 families.

The most dominant families recorded in the sites of Lower Dibang valley are Poaceae (10 species) and Meliaceae (7 species) followed by Euphorbiaceae, Araceae and Lauraceae with 6 species each. Whereas, the sites in Changlang district is dominated by the families Euphorbiaceae with 9 species, Araceae with 7 species and Lauraceae, Meliaceae and Moraceae with 5 species each followed by Arecaceae and Rubiaceae with 4 species. While, in sites under Pampumpare district the family Asteraceae and Araceae dominates with 6 species each followed by Dipterocarpaceae, Meliaceae, and Poaceae with 5 species each and Euphorbiaceae with 4 species.

Shannon-Wiener index of species diversity $\left(\mathrm{H}^{\prime}\right)$ of all the 9 studied sites were worked out and it is found that among the tree habit the Happy valley site of Changlang district has the highest diversity index with 3.68 followed by Ganga Lake of Papumpare district with 3.40 and 3.33 in Koronu of Lower Dibang Valley district (Table 2). Whereas, for shrubby species, the highest is found again in Happy Valley with 3.31 followed by Hornbill Camp area with 2.95 and with 2.90 Ganga Lake of Papumpare district. While among herbs, the highest diversity index is found in Hornbill Camp area with 3.55 followed by Happy valley with 3.41 both in Changlang district and 3.31 in Banderdewa of Papumpare district.
The important value index (IVI) of all the species were calculated and it is found that among the tree species in the sites of Changlang district, Shorea assamica (36.57) is the highest followed by Canarium strictum (22.8) in Debang Camp. In the sites of Papumpare district Duabanga grandifolia (36.37) is the highest followed by Mallotus philipensis (26.83) in Karsingsa. In Lower Dibang Valley sites the highest IVI is found for Terminalia myriocarpa (34.44) in Koronu site followed by Castanopsis indica (25.65) in Abongo Camp. Whereas, among the shrub species Phrynium pubinerve (32.20) in Ganga Lake has the highest IVI value followed by Thysanolaena latifolia (30.552) in Karsingsa of Papmpare district. Thysanolaena latifoloa (23.18) has the highest IVI in Koronu followed by Buddleja asiatica (22.59) in Bhismaknagar of Lower Dibang Valley and in Changlang district the highest IVI is found in Dendrocalamus hamiltonii (22.06) followed by Phrynium pubinerve (17.65) both in Hornbill Camp area. Among herbs species, the highest IVI is observed in Colocasia affinis (23.74) in Ganga Lake followed by Diplazium dilatatum (22.92) in Karsingsa of Papumpare district. The highest tree density is recorded in Happy Valley of Changlang district with 1435 individual ha-1 followed by, 995 individual ha-1 in Koronu of Lower Dibang Valley. While the highest shrub density is also recorded in Happy Valley of Changlang district with 3230 individual $\mathrm{ha}^{-1}$ followed by Banderdewa of Papumpare and Bhismaknagar of Lower Dibang Valley with 1825 individual ha-1 each. The highest density of herb species is also found in Happy Valley of Changlang district with 240375 individual $\mathrm{ha}^{-1}$ followed by Bhismaknagar of Lower Dibang Valley with 229375 individual ha-1. So, the density of all the habit forms is found highest in Happy Valley site of Changlang district. 


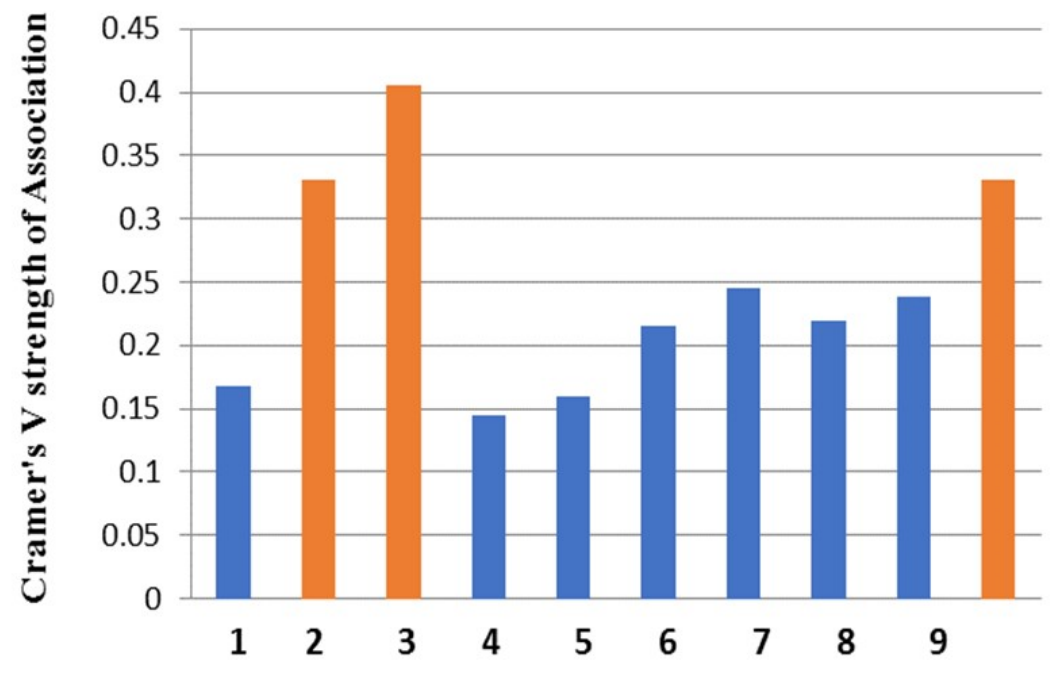

The associated species with $H$. aromatica
1. Alocasia fornicata

- 2. Amomum $s p$

-1. Aolocasia acuminata

- 4. Curcuma angustifolia

- 5. Diplazium dilatatum

6. Dryopteris sparsa

- 7. Floscopa scandens

- 8. Impatiens balsamina

9. Mikania micrantha

10. Pteris $s p$

Fig. 4. Species wise comparison on strength of association with Homalomena aromatica

Table 4: Pearson's correlation between population size and species diversity index

\begin{tabular}{cccc}
\hline & Tree diversity index & Shrub Diversity index & Herb diversity index \\
\hline Population of $H$. aromatca & $0.736^{*}$ & $0.900^{* *}$ & 0.392 \\
$P$ value & 0.024 & 0.001 & 0.296 \\
N & 9 & 9 & 9 \\
DF & 7 & 7 & 7 \\
\hline
\end{tabular}

*. Correlation is significant at the 0.05 level (2-tailed); ${ }^{* *}$. Correlation is significant at the 0.01 level (2-tailed).

Exploration study of Homalomena aromatica in Arunachal Pradesh

During the study, it was found that the Homalomena aromatica is distributed in the tropical evergreen and tropical semi evergreen forests of the state specifically at the adjoining areas of the state of Assam, within the altitude of $120 \mathrm{~m}$ to $600 \mathrm{~m}$ above sea level. Moreover, it was found that most of the individual populations of $H$. aromatica are distributed within the altitude of 350-450 meters above sea level (Fig. 2). Among the six selected districts, $H$. aromatica is recorded only in the three districts (Table 2). A total of 219 individuals are recorded from the 9 sites of three districts. Moreover, Changlang district represent the highest number of species with 137 individuals, followed by Papumpare with 42 individuals and Lower Dibang Valley with 40 individuals. It is recorded that the occurrence of higher number of species in the Changlang district is due to the presence of comparatively lesser threats on the target species. The values of IVI were also observed higher in one of the selected site Happy valley with 9.64 followed by Ganga Lake with 4.39. It was observed that the local people residing in and around the Namdapha National Park used to collect the species and their petiole are cooked as vegetables. Density (Individual $\mathrm{ha}^{-1}$ ) of the species was also determined and it was found that Happy Valley in Changlang has the highest density (14500
Individual $\left.\mathrm{ha}^{-1}\right)$ followed by Ganga Lake $(2250$ Individual $\mathrm{ha}^{-1}$ ) in Papumpare and Koronu (2000 Individual $\mathrm{ha}^{-1}$ ) in Lower Dibang Valley. Frequency \% of $H$. aromatic is observed highest in Happy Valley in Changlang (21.25\%) followed by Ganga Lake (12.5\%) in Papumpare.

During the survey, various threats to the population of the Homalomena aromatica have also been observed. Except in the sites of the Changlang district which are located inside the Namdapha National parks and one site the Ganga lake of Papum Pare district the species is threatened by various threats in all the sites. The threats namely landslides, heavy floods, road widening and urbanization, deforestation for agriculture, collection of rhizomes of the species and other resources like bamboo are observed (Table 2) The distributional status reveals that the species was found occurring sparsely in all the three study districts. Whereas, in the districts of West Kameng, East Siang and West Siang the species is not observed in the wild. However, it is found cultivated in the herbal gardens of College of Horticulture and Forestry and Indian Institute of Traditional Folk Medicine in East Siang district collected from the wild.

The effect of species diversity index on population of Homalomena aromatica.

The value of Shannon diversity index increases along with the increase in species richness and 
evenness of a particular community, which signifies that higher the index value means richer the diversity. The result on correlation between species diversity index and population of Homalomena aromatica shows that the highest was observed in the shrub species diversity index with significant positive relationship between $r(7)=0.900, p=0.001$ followed by tree species diversity index, $r(7)=0.736, p=0.024$ (Table 4). Wheras, a weak or no relationship was established between the poulation of $H$. aromatica and the species diversity index of herbs, $r(7)=0.39, p=0.269$.

\section{Regeneration status and species association of Homalomena aromatica}

The study on regeneration status of Homalomena aromatica in the selected plots reveals that the majority of the study sites are represented poor regeneration except for two study sites the Happy valley in Changlang district and Koronu in Lower Dibang Valley. Both the sites were representing good regeneration where the populations of the young plants are found more than the adult plants i.e. 68 young and 48 Adult in Happy Valley and 9 young and 7 adults in Koronu (Fig. 3).

The result on chi-square test of species association indicated that out of 45 selected associated species, 10 species are found with significantly higher association with Homalomena aromatica in the selected sites (Table 5). Among the top 10 associated species, Alocasia acuminata was found associated in two sites namely Ganga Lake of Papumpare district $\left(x^{2}=13.134, P=0.004\right)$ with 0.405 Cramer's V strength of association and Debang Camp of Changlang district $\left(x^{2}=11.88854\right.$, $P=0.007)$ with 0.385 Cramer's $\mathrm{V}$ strength of association respectively. Likewise, the other significantly high associated species are Amomum sp. $\left(\mathrm{x}^{2}=8.745, P=0.032\right)$ with 0.33 Cramer's V strength of association in Ganga Lake of Papumpare district and Pteris sp. (8.745, $P=0.33$ ) with 0.33 Cramer's V strength of association in Karsingsa of Papumpare district. Floscopa scandens $\left(\mathrm{x}^{2}=8.604 P=0.035\right)$ with 0.33 Cramer's V strength of association is found highly associated in Debang Camp of Changlang district (Table 5). The result on Cramer's V strength of association for all the associated species has revealed that the three species namely Alocasia accuinata (0.4); Amomum sp (0.33) and Pteris $s p(0.33)$. are found with stronger association with $H$. aromatica while the rest 7 species showed moderate association (Fig. 4).

\section{Discussion}

The present study revealed that the Homalomena aromatica is mostly distributed in small pockets at the foothill's areas of the Arunachal Pradesh bordering to the state of Assam in the tropical evergreen and semi-evergreen forest and also mixed bamboo forest in the altitudinal ranges between $120 \mathrm{~m}$ to $600 \mathrm{~m}$ asl. Nath et al. (44) also reported the occurrence of the species in the similar forest types in the state in the areas bordering to Assam. Referring to its micro-habitat the species is found growing in the humus rich, moist and nearby water channel with dense canopy cover providing a moist shady environment. The study has also revealed that the population of $H$. aromatica in the wild has been decreasing gradually and are not available in all the districts of the foothill's areas. Although the earlier occurrence of the species in the forest areas of East Siang district is encountered, we could not locate any individual or population in the selected sites of the district indicating its rareness or present non-availability. So, it can be stated that the environmental stochastic has influence the small and uneven population size to decline and hence leading towards its extinction locally.

The result on species richness in the habitats of the Homalomena aromatica indicated a rich floristic diversity with 288 species. It shows the species diversity of these areas is almost similar with the result of Nath et al. (45) from the tropical forest of Changlang district of Arunachal Pradesh where 200 species were recorded. The tree diversity of 116 species from the selected study sites were found much higher than the reported species from the tropical forests of Assam and Mizoram $(46,47)$. Kent and Coker (48) reported that Shannon-Weiner diversity index normally varies from 1.5 to 3.5 and rarely exceeds 4.5. In the present study also, the Shannon-Weiner diversity index was found in between 2.71 to 3.67 (Table 2). However, the value was found greater than Nath et al. (45) from the similar area i. e Tropical forest of Arunachal Pradesh. The tree density $(>15 \mathrm{~cm} \mathrm{DBH})$ in the selected sites varied from 475 to $1435 \mathrm{ha}^{-1}$ which are found greater than Swamy et al. (49) 436-971 stem per hectare. Whereas, the values are found lesser in comparison to the tree density of 3656 5452 stems per hectare by Bhuyan et al. (50) in wet evergreen forest of Arunachal Pradesh. However, the average tree densities in the tropical forests of various regions are found ranges from 245 to 859 stem per hectare $(51 ; 52$; 53). The Basal area recorded from the selected study sites ranged from 6.895 to $63.669 \mathrm{~m}^{2} \mathrm{ha}^{-1}$ for $>15 \mathrm{~cm}$ diameter threshold were found slightly below then the range recorded from different tropical forests by other workers like Barbhuiya et al. (54) as 98.6 ha-1, Swamy et al. (49) as 67.4 ha ${ }^{1}$ and Burges (55) as $73.6 \mathrm{ha}^{-1}$. The present study on basal area ranges of the tree species (Table 2) indicates that $H$. aromatica is found in different stages of succession from homeostasis Dipterocarpus forest with higher basal area in Changlang district to Secondary forest of Papumpare district with low basal area which are largely affected by anthropogenic activity like abandoned jhum and agriculture land resulting to 
Table 5: Chi-Square test of species association along with Cramer's V strength of association

\begin{tabular}{|c|c|c|c|c|c|c|c|c|c|c|c|c|c|c|c|c|c|c|c|}
\hline \multirow[t]{3}{*}{ Sl No } & \multirow[t]{3}{*}{ Name of Species } & \multicolumn{6}{|c|}{ Papumpare District } & \multicolumn{6}{|c|}{ Lower Dibang Valley District } & \multicolumn{6}{|c|}{ Changlang District } \\
\hline & & \multicolumn{2}{|c|}{ Site 1} & \multicolumn{2}{|c|}{ Site 2} & \multicolumn{2}{|c|}{ Site 3} & \multicolumn{2}{|c|}{ Site 1} & \multicolumn{2}{|c|}{ Site 2} & \multicolumn{2}{|c|}{ Site 3} & \multicolumn{2}{|c|}{ Site 1} & \multicolumn{2}{|c|}{ Site 2} & \multicolumn{2}{|c|}{ Site 3} \\
\hline & & $\begin{array}{l}\text { Chi } \\
\text { square }\end{array}$ & $\begin{array}{l}\text { Cramer } \\
\text { 's V }\end{array}$ & $\begin{array}{l}\text { Chi } \\
\text { square }\end{array}$ & $\begin{array}{c}\text { Cramer' } \\
\text { s V }\end{array}$ & $\begin{array}{l}\text { Chi } \\
\text { square }\end{array}$ & $\begin{array}{c}\text { Cramer' } \\
\text { s V }\end{array}$ & $\begin{array}{l}\text { Chi } \\
\text { square }\end{array}$ & $\begin{array}{c}\text { Cramer' } \\
\text { s V }\end{array}$ & $\begin{array}{l}\text { Chi } \\
\text { square }\end{array}$ & $\begin{array}{c}\text { Cramer' } \\
\text { s V }\end{array}$ & $\begin{array}{l}\text { Chi } \\
\text { square }\end{array}$ & $\underset{\text { 's V }}{\text { Cramer }}$ & $\begin{array}{l}\text { Chi } \\
\text { square }\end{array}$ & $\begin{array}{c}\text { Cramer's } \\
\text { V }\end{array}$ & $\begin{array}{l}\text { Chi } \\
\text { square }\end{array}$ & $\begin{array}{c}\text { Cramer's } \\
\text { V }\end{array}$ & $\begin{array}{l}\text { Chi } \\
\text { square }\end{array}$ & $\begin{array}{c}\text { Cramer's } \\
\text { V }\end{array}$ \\
\hline 1 & $\begin{array}{l}\text { Alocasia fornicate } \\
\text { (Araceae) }\end{array}$ & nil & nil & 0.034 & 0.143 & nil & nil & nil & nil & nil & nil & 1.602 & 0.142 & nil & nil & 3.870 & 0.219 & nil & nil \\
\hline 2 & $\begin{array}{l}\text { Alocasia acuminata } \\
\text { (Araceae) }\end{array}$ & 0.587 & 0.085 & 0.034 & 0.021 & 13.134 & 0.405 & 1.693 & 0.145 & nil & nil & 4.765 & 0.244 & nil & nil & 5.333 & 0.258 & 11.888 & 0.385 \\
\hline 3 & $\begin{array}{l}\text { Amomum sp } \\
\text { (Zingiberaceae) }\end{array}$ & nil & nil & 4.168 & 0.227 & 8.745 & 0.330 & nil & nil & nil & nil & nil & nil & nil & nil & 2.610 & 0.181 & nil & nil \\
\hline 4 & $\begin{array}{l}\text { Curcuma angustifolia } \\
\text { (Zingiberaceae) }\end{array}$ & 0.015 & 0.0137 & nil & nil & nil & nil & nil & nil & nil & nil & nil & nil & nil & nil & 6.037 & 0.274 & nil & nil \\
\hline 5 & $\begin{array}{l}\text { Diplazium dilatatum } \\
\text { (Athyriaceae) }\end{array}$ & nil & nil & 1.157 & 0.120 & 1.120 & 0.118 & nil & nil & nil & nil & 4.396 & 0.234 & nil & nil & 2.210 & 0.166 & nil & nil \\
\hline 6 & $\begin{array}{l}\text { Dryopteris sparsa } \\
\text { (Dryopteridaceae) }\end{array}$ & nil & nil & nil & nil & nil & nil & nil & nil & nil & nil & nil & nil & 2.470 & 0.175 & nil & nil & 5.167 & 0.254 \\
\hline 7 & $\begin{array}{l}\text { Floscopa scandens } \\
\text { (Commelinaceae }\end{array}$ & nil & nil & nil & nil & nil & nil & nil & nil & nil & nil & nil & nil & nil & nil & nil & nil & 8.604 & 0.327 \\
\hline 8 & $\begin{array}{l}\text { Impatiens balsamina } \\
\text { (Balsaminaceae) }\end{array}$ & 5.473 & 0.261 & nil & nil & nil & nil & nil & nil & nil & nil & nil & nil & nil & nil & nil & nil & nil & nil \\
\hline 9 & $\begin{array}{l}\text { Mikania micrantha } \\
\text { (Asteraceae) }\end{array}$ & 2.845 & 0.188 & nil & nil & nil & nil & nil & nil & nil & nil & 6.655 & 0.288 & nil & nil & nil & nil & nil & nil \\
\hline 10 & $\begin{array}{l}\text { Pteris sp } \\
\text { (Pteridaceae) }\end{array}$ & nil & nil & 8.745 & 0.331 & 3.484 & 0.208 & nil & nil & 1.901 & 0.154 & 5.168 & 0.254 & nil & nil & nil & nil & nil & nil \\
\hline
\end{tabular}

Note: Papumpare: site1=Banderdewa, site2=Karsingsa, site3= Ganga Lake; Lower Dibang Valley: site1=Koronu, site2=Bismaknagar, site3= Abongo Camp; Changlang: site1=Happy Valley, site2= Hornbill Camp area, site3= Deban Camp 
landslide. The differences in species composition, successional stage of the forest, age structure and degree of disturbance contributes in size of basal area $(49,56)$. The initiation of a successional process is strongly influence by major natural disturbances like landslide, hurricane, flood and windstorm $(57,58,59)$

The result on Pearson's correlation has reveals that there is a positive relationship between the population of Homalomena aromatica and the diversity index of tree, shrub. The strongest relationship of the population of $H$. aromatica with shrubs and trees has supported the fact that there is no close competition between shrub and tree species with $H$ aromatica. So, it has been found that high species diversity in a habitat has a positive influence in maintaining the population of the rare species $H$. aromatica in the study site. However, there was no significant relationship with herb diversity index. It was found that invasive species like Mikania micrantha was associated with $H$. aromatica in Banderdewa and Abongo camp. The Mikania micrantha is a top invasive species with diverse distributional range and a larger extent of the Indian landmass is climatically suitable for $M$. micrantha growth (60). So, it can be said that $M$. micrantha could become a threat to $H$. aromatica as it shares the same habitat.

The species importance value index (IVI) represents the ecological success of the species. The higher the value known to be dominance and success of the species and lower the value, the less success of the species in establishing itself in the forest $(61 ; 62)$. The IVI of Homalomena aromatica from the 9 selected sites, revealed that except the Happy Valley of Changlang district where the IVI is 9.64, it is found lower than 5 in rest of the sites. It shows that the IVI values of the $H$. aromatica are comparatively lower than many other species. Density Individual ha ${ }^{-1}$ of $H$. aromatica revealed that the highest was observed in Happy Valley of Changlang district (14500) and Ganga Lake (2250) in Papumpare district. The higher density of the species in these two sites attributed to least anthropogenic activities as both of the plots are under protected area as the Happy Valley falls under Namdapha National Park and the Ganga Lake a recreational park located under Itanagar Wild Life Sanctuary. The protection of habitat in these two sites has supported the better population of $H$. aromatica in wild. Dattagupta (63) reported the similar density of the species in three selected sites from Assam (ranges from 4608 to 7360 Individual ha-1). However, the frequency \% of $H$. aromatica in the present study is comparatively lower ( $5 \%$ to $21 \%$ ), than the reported values (ranges from $69.6 \%$ to $80 \%$ ) by Dattagupta (63). The results clearly indicated the biotic factors are directly influencing the population. The abundance of individuals is affected by biotic factors (64). The result on population structure of
$H$. aromatica reveals that Happy Valley of Changlang district and Koronu of Lower Dibang Valley shows good regeneration while the rest of the 7 sites indicate the poor regeneration. Spellerberg (65) described that an uneven age structure or sex ratio in a population can precipitate its decline to extinction, while a balanced birth and death rates would ensure rapid growth. Moreover, the phenological observations of $H$. aromatica showed that the whole inflorescence dried up just after the anthesis (flowering period) without development of fruits in all the study sites. Kusuma and Astuti (10) has also reported that the species of Araceae family has its unique transition from sexual to vegetative reproduction along with very less flowering and fruiting. The low existing population of the species with the failure in regeneration through production of seeds threatened the existence of $H$. aromatica in the wild. The habitat of $\mathrm{H}$. aromatica is exclusively in the forests and the species occur mostly in moist environment under deep shady forest floors. So, considering the habitat specificity and limited occurrence of $H$. aromatica, understanding and identifying the associated species could help to trace this rare species. Among the 10 closely associated species observed, the three species Alocasia acuminata (Aracaceae), Amomum sp. (Zingiberaceae) and Pteris sp. (Pteridaceae) are significantly associated with $H$. aromatica with stronger Cramer's $\mathrm{V}$ strength of association. The importance of associated species to trace the population of some rare species like Swertia chirayita, Paris polyphylla, and Panax bipinnatifidus has also been indicated by Lyngdoh (66) from Eastern Himalaya. The species association are important indicator for locating the species and are also useful in conservation and monitoring of vegetation change (67).

\section{Conclusions}

The present study explored and highlighted the present status of its distribution and population of the economically important species Homalomena aromatica. The low population status with very limited individuals (219 nos.) and poor regeneration status has been found challenging for the survival of the species in the wild. The species may be treated as critically endangered in the state. Moreover, the various anthropogenic activities like collection or resources, clearance forests for agriculture, the developmental activities like road widening, urbanization, etc. and the natural calamities like heavy flood and landslide have threatened the habitat and its population in the different forest areas. The failure of reproductive cycle has additionally challenged the stability of the species, limiting its dispersal and regeneration. So, the present findings emphasize on more future critical studies on reproductive biology, entomopalynology, and 
palynology of $H$. aromatica. The present study has also provided some valuable information like community characters of $H$. aromatica habitats and species composition; species association and relationship between the population size and species diversity index, which are assumed as important parameter for conservation and management of the species. There is a need of extensive and thorough survey in other forests areas of the state to locate additional distributional areas so that some suitable sites can be selected for its in-situ conservation. Moreover, there is also a need of ex-situ conservation by introducing the species in different institutional areas and botanic garden and promoting of its commercial cultivation.

\section{Conflict of interest}

The authors declared that they have no conflict of interest.

\section{Author's Contribution}

PRG, KR and BS designed the objectives and planned the work. KR undertaken the field survey and data analysis. KR and PRG formulated and finalized the manuscript.

\section{Acknowledgements}

The Authors are thankful to the Department of Environment and Forest, Govt. of Arunachal Pradesh for permission and support in field works in various forest areas. We also thank Dr. Kabuk Lego, Deputy Ranger, Mehao Wildlife Sanctuary and Forest officials of Namdapha Tiger Reserved and National Park for necessary help and support during field work. The help and information rendered by the local people of different study sites is duly acknowledged. The authors are also grateful to the Director of NERIST for providing necessary facilities. The study was undertaken as a part of the financial grant received from North Eastern Council (NEC) Govt. of India for medicinal plants.

\section{References}

1. Secretariat of the Convention on Biological Diversity. Strategic Plan for Biodiversity 2011-2020 and the Aichi targets. Montreal 2010; Available at http://www.cbd.int/doc/strategic-plan/2011-2020/AichiTargets-EN.pdf.

2. Pimm SL, Russell GJ, Gittleman JL, Brooks TM. The future of Biodiversity Science 1995; 269 (5222): 347$530 \quad$ Available http://www.sciencemag.org/content/269/5222/347.

3. Broennimann O, Vittoz P, Moser D, Guisan A. Rarity types among plant species with high conservation priority in Switzerland. Botanica Helvetica 2005; 115(2): 95-108. http://dx.doi.org/10.1007/s00035-0050713-Z
4. Lavergne S, Thuiller W, Molina J, Debussche M. Environmental and human factors influencing rare plant local occurrence, extinction and persistence: a 115-year study in the Mediterranean region. Journal of Biogeography 2005; 32(5): 799-811. http://dx.doi.org/10.1111/j.1365-2699.2005.01207.x.

5. Lomba A, Pellissier L, Randin C, Vicente J, Moreira F, Honrado J, et al. Overcoming the rare species modelling paradox: A novel hierarchical framework applied to an Iberian endemic plant. Biological Conservation 2010; 143(11): 2647-2657. https://doi.org/ 10.1016/j.biocon.2010.07.007

6. Hoffmann MH, Ermakov NB. Biogeographical study of West Siberian hemiboreal forest associations with species range overlay methods. Flora 2008;203(3): 234242. https://doi.org/10.1016/j.flora.2007.01.004

7. The Plant List Available at http://www.theplantlist.org/ browse/A/Araceae/Homalomena/

8. Botanical Survey of India. Checklist of Plants of India: Araceae. 2019. Available at http://efloraindia.nic.in/efloraindia/genusList PCL.action? resultType=familyWise\&parent $\mathrm{Id}=1830 \&$ parent Name $=\mathrm{A}$ RACEAE

9. Křenová Z, Lepš J. Regeneration of a Gentiana pneumonanthe population in an oligotrophic wet meadow. Journal of vegetation Science 1996; 7(1): 10712.

10. Kusuma YW, Astuti IP. Population and microhabitat characteristic of Homalomena bellula Schott in Mount Slamet, Central Java, Indonesia. Biodiversitas Journal of Biological Diversity 2009; 10(4): 201-205. https://doi.org/10.13057/biodiv/d100407

11. Choudhury BI, Khan ML, Arunachalam A, Das AK. Ecology and conservation of the critically endangered tree species Gymnocladus assamicus in Arunachal Pradesh, India. International Journal of Ecology 2007;5. https://doi.org/doi:10.1155/2007/59282

12. Paul A, Gajurel PR, Das AK. Threats and conservation of Paris polyphylla an endangered, highly exploited medicinal plant in the Indian Himalayan Region. Biodiversitas 2015; https://doi.org/10.13057/biodiv/d160226

13. Das AK, Singha LB, Khan ML. Community structure and species diversity of Pinus merkusii Jungh. \& de Vriese forest along an altitudinal gradient in Eastern Himalaya, Arunachal Pradesh, India. Tropical Ecology 2017; 58(2): 397-408.

14. Kehie P, Pfoze NL. Phytochemical and ethnopharmacological overview of endangered Homalomena aromatica Schott: An aromatic medicinal herb of Northeast India. Indian Journal of Natural Products and Resources (IJNPR)[Formerly Natural Product Radiance (NPR)]. 2017;8(1):18-31.

15. Ahmed, M. Hand book on Medicinal and Aromatic Plants. (Package of Practices). NEDFi, Guwahati. 2005; 33-38.

16. Nath M, Dutta BK, Hajra PK. Medicinal plants used in major diseases by Dimasa tribe of Barak valley. Assam University Journal of Science and Technology 2011; 7(1):18-26.

17. Kar A, Borthakur SK. Wild vegetables of Karbi-anglong district, Assam. Natural Product Radiance 2008; 7(5): 448-460.

18. Duta Choudhury M. Ethnomedico botanical aspects of Reang tribe of Assam: a comprehensive study. Ph. D. thesis, Gauhati University, India 1999 Available at 
http://ir.inflibnet.ac.in:8080/jspui/bitstream/10603/6633 3/12/12 discussion.pdf

19. Majumdar K, Datta BK. A study on ethnomedicinal usage of plants among the folklore herbalists and Tripuri medical practitioners: Part-II. Natural product Radiance 2007; 6(1): 66-73.

20. Khan MH, Yadava PS. Herbal remedies of asthma in Thoubal district of Manipur in North East India. Indian Journal of Natural Products \& Resources 2010; 1(1): 8084.

21. Rana S, Islam M, Bosunia SN, Mahmud SR, Santa SA Snigdha SH, Mahal MJ, Rahmatullah M. A survey of medicinal plants used by a village folk medicinal practitioner in Sreemangal Upazila of Maulvibazar district, Bangladesh. American-Eurasian Journal of Sustainable Agriculture 2014; 8(1): 1-9.

22. Baruah M. Micro morphology and antimicrobial activity of Homalomena aromatica (Spreng.) Schott: A potential aromatic. In S.I. Bhuyan and Sony Kumari (Eds.), Advance in Plant Research. 2015; 228-235, EBH Publishers Guwahati, India. ISBN: 9789383252619.

23. Gramer A. Antibiotic Sensitivity and Assay Test. Butterworth and Co., London 1976.

24. Policegoudra RS, Goswami S, Aradhya SM, Chatterjee S, Datta S, Sivaswamy R, Chattopadhyay P, Singh L. Bioactive constituents of Homalomena aromatica essential oil and its antifungal activity against dermatophytes and yeasts. Journal of Medical Mycology 2012; $22(1)$ : 83-7. https://doi.org/10.1016/j.mycmed.2011.10.007

25. Chandana CB, Anindita T, Acheenta GB, Debesh CP. Ulcer protective activity of ethanolic extract of Homalomena aromatica (Spreng.) Schott. Araceae) Root. Advanced Techniques in Biology and Medicine 2014; 2(1): 2-8. http://dx.doi.org/10.4172/albm.1000117

26. Hazarika S, Dhiman S, Rabha B, Bhola RK, Singh L, Smagghe G. Repellent activity of some essential oils against Simulium species in India. Journal of Insect Science 2012;

12(1):5. https://doi.org/10.1673/031.012.0501

27. Watkinson G. Homalomena lauterbachii. The IUCN Red List of Threatened species 2013: e.T44393130A44528996. http://dx.doi.org/102305/IUCN UK.2013-1.RLTS.T44393130A44528996.en.

28. Nayar MP, Sastry ARK. Red Data Book of Indian Plants. Vol. 1-3. Botanical Survey of India, Calcutta 1990

29. Ved DK, Kinhal GA, Haridasan K, Ravikumar K, Ghate U, Sankar RV, Indresha JH. (eds.). Conservation assessment and management prioritisation for the medicinal plants of Arunachal Pradesh, Assam, Meghalaya and Sikkim. Proceedings of the workshop 'Conservation assessment and management prioritisation for the medicinal plants of Arunachal Pradesh, Assam, Meghalaya and Sikkim,' Guwahati, 27 February to 1 March 2003. Foundation for Revitalisation of Local Health Traditions (FRLHT), Bangalore, India.

30. Gajurel PR, Ronald Kh, Buragohain R, Rethy P, Singh B, Potsangbam S. On the present status of distribution and threats of high value medicinal plants in the higher altitude forests of the Indian eastern Himalaya. Journal of Threatened Taxa 2015; 7(6): 7243-7252. https://doi.org/10.11609/JoTT.04041.7243-52

31. Ronald KH, Gajural PR, Buragohain R, Rethy P, Singh B. Poor phyto-sociological status of medicinal plants in Eastern Himalaya: Case study on the present scenario of some rare and economically important medicinal plants. Folia Malaysiana 2016; 18(1): 43-56.

32. Wikipedia, 2017. Available at https://en.wikipedia.org/ wiki/Eastern Himalaya

33. Champion SH, Seth SK. A revised survey of the forest types of India. A revised survey of the forest types of India. 1968

34. Kaul RN, Haridasan K. Forest types of Arunachal Pradesh: a preliminary study. Journal of Economic and Taxonomic Botany 1987; 9(2): 379-389.

35. Jain SK, Rao RR. A Handbook of Field and Herbarium Technique. Today and Tomorrow Publishers, New Delhi, India. 1977.

36. Misra R. Ecology Work Book. Oxford and IBH Publishing Company, New Delhi, India. 1968;244.

37. Mueller-Dombois D, Ellenberg H. Aims and Methods of Vegetation Ecology. John Wiley and Sons, New York, USA 1974:547.

38. Shannon CE, Weaver W. The Mathematical Theory of Communities. University of Illionis Press, Urbana 1963.

39. IBM Corp. Released 2010. IBM SPSS Statistics for Windows, Version 19.0. Armonk, NY: IBM Corp.

40. Whitford PB. Distribution of woodland plants in relation to succession and clonal growth. Ecology 1949; 30: $199-208$

41. Shankar U. A case of high tree diversity in a Sal (Shorea robusta)-dominated lowland forest of Eastern Himalaya: floristic composition, regeneration and conservation. Current Science 2001; 81(7): 776-786.

42. Whittaker, R.H. Communities and Ecosystems. $2^{\text {nd }}$ edn. Macmillan, New York. 1975.

43. Cramér H. Methods of Mathematical Statistics. Princeton: Princeton University Press. 1946.

44. Hore DK. Bioprospecting of Two Wild Plants: Paved Their way towards Commercialization. In Proceeding of International Seminar on "Multidisciplinary Approaches in Angiosperm Systematics" at Kalyani University, Kalyani. 2008; 726-729.

45. Nath PC, Arunachalam A, Khan ML, Arunachalam K, Barbhuiya AR. Vegetation analysis and tree population structure of tropical wet evergreen forests in and around Namdapha National Park, northeast India. Biodiversity \& Conservation 2005; 14(9): 21092135. https://doi.org/10.1007/s10531-004-4361-1

46. Sarkar M, Devi A. Assessment of diversity, population structure and regeneration status of tree species in Hollongapar Gibbon Wildlife Sanctuary, Assam, Northeast India. Tropical Plant Research 2014;1(2): 2636

47. Lalfakawma, Sahoo UK, Roy S, Vanlalhriatpuia K, Vanalalhluna PC. Community composition and tree population structure in undisturbed and disturbed tropical semi-evergreen forest stands of north-east India. Ecology and Environmental Research 2009; 7: 303-318

48. Kent M, Coker P. Vegetation Description and Analysis: A practical Approach. Belhaven Press, London 1992.

49. Swamy PS, Sundarandian SM, Chandrasekar P, Chandrasekaran S. Plant species diversity and tree population structure of a humid tropical forest in Tamil Nadu, India. Biodiversity Conservation 2000; 9:1643-1669. 
50. Bhuyan P, Khan ML, Tripathi RS. Tree diversity and population structure in undisturbed and humanimpacted stands of tropical wet evergreen forest in Arunachal Pradesh, Eastern Himalayas, India. Biodiversity Conservation 2003; 12(8): 1753-1773.

51. Richards PW. The Tropical Rain Forest. Cambridge University Press, London 1952.

52. Ashton PS. A quantitative phytosociological technique applied to tropical mixed rain forest vegetation. Malayan Forester 1964; 27: 304-317

53. Campbell DG, Stone JL, Rosas AJr. A comparison of the phytosociology and dynamics of three floodplain (Varzea) forests of known ages, Rio Jurua, western Brazilian Amazon. Botanical Journal of the Linnean Society 1992; 108: 213-237

54. Barbhuiya AR, Arunachalam A, Nath PC, Khan ML, Arunachalam K. Leaf litter decomposition of dominant tree species of Namdapha National Park, Arunachal Pradesh, northeast India. Journal of Forest Research 2008; 13(1): 25-34. https://doi.org/10.1007/s10310-007$\underline{0044-6}$

55. Burgess PF. The Structure and Composition of Lowland Rainforest in North Borneo. Malayan Forester 1961; 14: 66-80.

56. Sundarapandian SM. Ecological studies on forest ecosystem at Kodayar in Western Ghats of Tamil Nadu. Ph. D. Thesis, Madurai Kamaraj University, Madurai, $1997 ; 113$

57. Waide $\mathrm{RB}$, and Lugo AE. A research perspective on disturbance and recovery of a tropical forest. In J.G. Goldammer (ed.), Tropical Forests in Transition. Birkhauser, Basel, Switzerland, 1992;173-189.

58. Whitmore TC, Burslem DFRP. Major disturbances in tropical rainforests. In D.M. Newbery, H.H.T. Prins, and N.D. Brown (eds), Dynamics of Tropical Communities. Blackwell Science Ltd, Oxford, 1998; 549-565.

59. Chazdon RL. Tropical forest recovery: Legacies of human impact and natural disturbances. Perspectives in Plant Ecology, Evolution and Systematics 2003; 6(12): 51-71.

60. Banerjee AK, Mukherjee A, Dewanji A. Potential distribution of Mikania micrantha Kunth in Indiaevidence of climatic niche and biome shifts. Flora 2017; 234: 215-223. https://doi.org/10.1016/j.flora.2017.08.001

61. Gokhale Y, Negi AK (eds). Community-based Biodiversity Conservation in the Himalayas. The Energy and Resources Institute (TERI), New Delhi. 2011.

62. Parthasarathy N. Biodiversity and population density of woody species in a tropical evergreen forest in Courtallum reserve forest, Western Ghats, India. Tropical Ecology 1997; 38: 297-306.

63. Dattagupta S. Inventory and assessment of plant and animal NTFP in inner line reserve Forest Cachar, Assam, India. Ph. D thesis, Assam University, Shilchar. 2011 Available at http://hdl.handle.net/10603/92880

64. Medel-Narvaez A, de la Luz JL, Freaner-Martinez F, Molina-Freaner F. Patterns of abundance and population structure of Pachycereus pringlei (Cactaceae), a columnar cactus of the Sonoran Desert. Plant Ecology 2006; 187(1):1-4 https://doi.org/10.1007/s11258-006-9128-1

65. Spellerberg IF. Conservation Biology. Longman Publisher, Harlow, England 1996.

66. Lyngdoh MK. Population ecology of threatened ethno_medicinal plant species in relation to forest fragmentation in Kanchendzonga Biosphere Reserve Sikkim. Ph. D thesis, North Eastern Hill University (NEHU), Shillong. 2011

67. Munishi PK, Temu RA, Soka G. Plant communities and tree species associations in a Miombo ecosystem in the Lake Rukwa basin, Southern Tanzania: Implications for conservation. Journal of Ecology and the Natural Environment 2010; 3(2): 63-71. 